\title{
UNIVERSITYOF
}

FORWARD

THINKING

WESTMINSTER用

WestminsterResearch

http://www.westminster.ac.uk/westminsterresearch

The Effects of Knowledge Spillovers and Accelerator

Programmes on the Product Innovation of High-Tech Start-ups: A

Multiple Case Study

Cuvero, M., Granados, M., Pilkington, A. and Evans, R.D.

This is a copy of the author's accepted version of a paper subsequently published in IEEE Transactions on Engineering Management.

It is available online at:

https://dx.doi.org/10.1109/TEM.2019.2923250

(C) 2019 IEEE . Personal use of this material is permitted. Permission from IEEE must be obtained for all other uses, in any current or future media, including reprinting/republishing this material for advertising or promotional purposes, creating new collective works, for resale or redistribution to servers or lists, or reuse of any copyrighted component of this work in other works.

The WestminsterResearch online digital archive at the University of Westminster aims to make the research output of the University available to a wider audience. Copyright and Moral Rights remain with the authors and/or copyright owners.

Whilst further distribution of specific materials from within this archive is forbidden, you may freely distribute the URL of WestminsterResearch: ((http://westminsterresearch.wmin.ac.uk/)).

In case of abuse or copyright appearing without permission e-mail repository@westminster.ac.uk 
4. IEEE TRANSACTIONS ON

FNGINHHRING

MANAGFMENT

\section{The Effects of Knowledge Spillovers and Accelerator Programmes on the Product Innovation of High-Tech Start- ups: A Multiple Case Study}

\begin{tabular}{|r|l|}
\hline Journal: & Transactions on Engineering Management \\
\hline Manuscript ID & TEM-19-0067.R1 \\
\hline Manuscript Type: & $\begin{array}{l}\text { Special Section: Incubators and Accelerators: Integrating evolving } \\
\text { incubator models and learning from the past }\end{array}$ \\
\hline Keywords: & $\begin{array}{l}\text { Knowledge Spillovers, Entrepreneurship, High-Tech Start-ups, Product } \\
\text { Innovation, Absorptive Capacity, Accelerator programmes }\end{array}$ \\
\hline Subject Category: & $\begin{array}{l}\text { Entrepreneurship, Integrating Technology for Capability and Productivity, } \\
\text { Managing Technological Innovation - New Product/Service Development } \\
\text { and R\&D Management, Moving Product/Services from Idea to Market }\end{array}$ \\
\hline
\end{tabular}

\section{SCHOLARONE \\ Manuscripts}




\title{
The Effects of Knowledge Spillovers and Accelerator Programmes on the Product Innovation of High-Tech Start-ups: A Multiple Case Study
}

\begin{abstract}
The Knowledge Spillover Theory of Entrepreneurship (KSTE) explores the effects that new knowledge and proximity have on the exploitation of entrepreneurial opportunities and the resultant creation of start-ups. This paper aims to identify the types of knowledge spillovers that affect entrepreneurs in the early stages of start-up development. A conceptual model is proposed, using a multi-case study approach involving High-Tech start-ups that have attended accelerator and incubator programmes in Greater London, United Kingdom (UK). The research involved 32 semistructured interviews with Chief Executive Officers (CEOs) and co-founders of start-up companies. Our findings suggest that entrepreneurs are influenced by various forms of knowledge spillover which assist in determining the strategic decision of the company, in terms of formation, including partnerships or alliances, allocation of Research and Development (R\&D) budgets, and engagement in product innovation. Further observations confirm that High-tech start-ups focus on a fast pace of constant product innovation to cover identified gaps in the market. One significant finding is that start-ups use various technological platforms to access knowledge spillovers which challenges the ideas of geographical proximity present in existing KSTE understanding.
\end{abstract}

Index Terms: Knowledge Spillovers; Entrepreneurship; High-Tech Start-ups; Product Innovation; Absorptive Capacity; Accelerator programmes.

\section{Managerial Relevance}

This research provides managers involved in start-up creation with insights into the critical earlystage knowledge and resources required to ground a firm from business idea and sheds light on the 
managerial decisions required to remain competitive in turbulent markets. First, this paper examines the knowledge spillovers which can be accumulated from industrial and academic sources to influence managerial decisions taken by start-ups; decisions can include the geographical location of the company headquarters and the industrial sector which they choose to operate within. Secondly, it studies the impact that accelerator and incubator programmes have on start-ups in gathering knowledge which determines the initial company processes and their wider network; we suggest opportunities for obtaining funding, gaining insights on local and international markets, and engaging in collaboration with established companies. Finally, the study emphasizes the importance for high-tech start-ups of hiring highly skilled capital to operate technological tools to allow for the collection of knowledge and to maintain collaborations and partnerships for constant product innovation. These insights are integrated into a conceptual framework that increases the opportunities of start-up survival.

\section{INTRODUCTION}

Knowledge spillovers are perceived as the result of unexploited knowledge generated from R\&D investment [7, 8]. Research into knowledge spillovers stemmed from the model proposed by Schumpeter [9] in which entrepreneurs acted as economic agents that transformed unexploited knowledge into economic knowledge through the creation of new ventures [10]. Further development of this model, in conjunction with increased interest in innovation and economic growth, led to the development of the Knowledge Spillover Theory of Entrepreneurship [7]. This assumes that entrepreneurs obtain technical knowledge from external sources [6] and then proceed to develop economic knowledge by starting a new company leading to the creation of new ventures and employment $[11,12]$. 
Engagement in entrepreneurial activities that result in the commercialization of new businesses is triggered by the cultural diversity present in cities $[6,13]$. Therefore, access to and usage of knowledge spillovers increase when entrepreneurs are located close to sources of knowledge, including universities, companies and research institutions [11, 14, 15]. In addition, competition and high levels of productivity in incumbents forces entrepreneurs to access new sources of knowledge to facilitate innovation $[13,16]$. As a result, start-ups rely heavily on technological knowledge spillovers, while maintaining formal knowledge management mechanisms to prevent knowledge leakage to competitors [17]. Researchers have extensively studied the exchange of knowledge spillovers and R\&D investment in high-tech and manufacturing sectors at the regional level by analyzing the effects of networks and collaborations $[6,15]$. This research argues that companies located in entrepreneurial and industrial clusters gain economic and innovative advantage [1] through engagement with Science and Technology Parks (STPs) and universities $[18,19]$. Research into knowledge spillovers and entrepreneurship continues to be a broad domain that requires further definition [20]. Most research has been focused at the regional level, and showing that start-up companies have only a 50-60 percent survival chance before the seventh year $[21,22]$. To address this shortcoming, this paper plans to uncover the practices and mechanisms used by founders and entrepreneurs to capture and implement knowledge spillovers for successful maturity [23]. By doing this, we examine the variables and mechanisms to measure the impact of knowledge spillovers on organizational outcomes and suggest this as the basis for future research $[1,8,24]$.

This paper also considers the influence that the education and experience of the initial founders have on the creation of new ventures $[25,26]$. These characteristics are essential for identifying entrepreneurial opportunities that generate revenue in start-ups and increases the opportunities for business survival [27]. In essence, CEOs require a necessary skillset to materialize a business idea 
into the development of a new company [28]. Our contribution to theory and practice lies in the uncovering of knowledge spillovers required by CEOs during the business idea, seed and growth stages of the company. A multiple case study approach was adopted involving High-Tech start-ups that attended accelerator and incubator programmes in the Greater London area of the UK; this was supported by 32 semi-structured interviews with the CEOs and start-up co-founders. Our contribution to the field of KSTE is threefold: (1) we develop a conceptual model representing the effects of knowledge spillovers at the individual entrepreneur level that provides a grounding for the assessment of knowledge spillovers; (2) we develop a series of propositions that highlight the effects that knowledge spillovers have on start-up development and absorptive capacity; and (3) we identify empirically the mechanisms and sources used by CEOs to capture and implement knowledge spillovers for product innovation which informs practice and supports innovation initiatives.

The remainder of this paper is structured as follows. In Section II, we review currently-available literature on knowledge spillovers, entrepreneurs, start-ups, accelerator programmes, corporate networking, absorptive capacity and knowledge implementation. In Section III, we present our methodology, data sampling and data collection techniques, and data analysis methods. Section IV presents the results. Sections V and VI discuss findings and draw conclusions.

\section{THEORETICAL BACKGROUND}

\section{A. Definition of Knowledge Spillovers}

Knowledge spillover relates to the informal capture of new knowledge which is obtained and used to commercialize a product or service in the market. Knowledge generated in a company or research institution which is left uncommercialized can be considered a source of further extraentrepreneurial opportunity [29]. This knowledge, which can relate to production processes, the 
implementation of new technologies, or the development of materials [30]can be subsequently captured through an entrepreneur's absorptive capacity and exploited in a new market. This is knowledge spillover [6, 29, 31]. Important characteristics of knowledge spillovers are that they are difficult to measure and so hard to determine their economic value as they do not typically provide a direct benefit to the creator of the knowledge [12, 24].

There are different types of knowledge spillover. For instance, tacit knowledge spillovers, which are often difficult to transmit and are typically received via face-to-face interactions, come from the previous experience and knowledge that is informaly shared between individuals. Alternatively, explicit knowledge spillovers can be public or codified and can be present in published material e.g., books, patents, industry reports [15, 28]. Other types of knowledge spillovers relate to the geographical location and proximity to sources of knowledge, such as universities, companies, and governments [23]. These types of knowledge spillovers are generated from R\&D and are accessible in the public domain and used in various industrial sectors [35]. Technological knowledge spillovers are the various types of information that come from the disciplines of technology and engineering that enable innovation [23].

Other types of knowledge spillovers accessible to entrepreneurs are market knowledge, entrepreneurial knowledge and international knowledge [1, 30]. Entrepreneurial knowledge spillovers can be attained from the direct exchange of knowledge between entrepreneurs and the market to develop a Minimum Viable Product (MVP), and the business knowledge necessary to obtain funding for the company [1]. Here, entrepreneurs can access explicit knowledge in the public domain created from R\&D investment from companies [31, 23]. Lastly, tacit and explicit knowledge spillovers can be examined from their various originators, including suppliers, customers, competitors and research institutions [18, 36]. 


\section{B. The relationship between entrepreneur background and the Start-up in knowledge spillovers}

The experience and academic qualifications of entrepreneurs are proxies for the potential level of absorptive capacity that start-ups have in their early stages of operation [32]. As such, the identification of an initial business idea influences the managerial and technical decision to engage in the development of a new product $[18,23]$. This initial decision, based on unexploited knowledge spillovers, leads to an initial financial evaluation that influences the decision to leave secure employment and to engage in the creation of a new company [25, 38, 39]. Moreover, previous technical and managerial experiences can lead to the utilization of similar technological systems from the parent organization, which itself can cause the formation of spinoffs or influenced entrepreneurial endeavors [40]. The network capital that CEOs have built during their industrial career and academic progression facilitates initial connections for future alliances that can secure access to resources and funding increasing the survival chances of start-ups [7, 32].

Geographical proximity to sources of knowledge is also a factor that has been shown to influence decisions, primarily regarding locating a company in a specific region $[10,41]$. As start-ups develop and gain market experience, companies progress in the start-up cycle, which includes the stages of seed, venture growth, business stabilization, and product diversification, as well as a potential final decline or creative destruction [1, 42]. Hence, the commitment of an entrepreneur to develop a new start-up depends on their decision to identify entrepreneurial opportunities (Nascent entrepreneurship) or to pursue the creation of a new-business [7]. The characteristics of CEOs and the employees of the company are indicators of the potential to engage in innovative endeavors [5]. Although studies have recognized the influence of entrepreneur background, there is still a need to better understand the effects of this on knowledge spillovers at the individual level of the entrepreneur. 


\section{Accelerator Programmes and Networking}

Recently, new physical locations, provided through incubators, open spaces, and accelerators, have been shown influence the creation of entrepreneurial ecosystems and facilitate access to financial investment from angel investors and venture capitalists [43, 44]. This supplements previous research showing the positive influence that science and technology parks have on start-up development $[1,18]$. In particular, accelerator programmes provide short term training, access to industry experts, and the opportunity to access a network of companies, These feature predominantly in cities that present high economic growth [15, 45]. Attendance of an accelerator or open ended incubator program provides the opportunity to use facilities that reduce operational costs and provide access to necessary assets to run a company in the early stages [46].

The capacity and services provided in such programmes act as mechanisms that enable access to knowledge spillovers outside the boundaries of a geographical location [30, 18]. Hence, accelerator programmes and incubators can influence the development of start-ups by providing strategic advice and technical knowledge to achieve short and long term goals [46]. Sources of knowledge in these start-up support systems include entrepreneurial events that can be exploited to increase exposure of business ideas to investors and to engage with potential partners to develop collaborations [43, 44]. By uncovering the mechanisms used by CEOs and entrepreneurs as part of these situations, we can start to understand how knowledge spillovers are used to develop alliances and engage with product and process innovation [41].

The exchange of informal knowledge between individuals and companies can be disrupted by the perceived negative effects of knowledge leakage and competition and can be considered as a source of future hazards $[13,16,47]$. Nonetheless, when start-ups are faced by adversity, it can be a source of motivation that incentivizes entrepreneurs to promote the implementation and development of technological knowledge, and to engage in alliances that boost the possibility of survival. The 
KSTE has provided research on how the development of collaborations between companies stimulate $R \& D$ on the creation of new patents and new technologies [43]. Thus, the creation of formal alliances and establishing common projects leads to product innovation by sharing resources, facilities, and human capital $[47,48]$. In this study, we aim to understand these alliances and the role of accelerator programmes on knowledge spillovers at the individual level.

\section{Absorptive Capacity and Knowledge Implementation}

Absorptive capacity represents the capability of a company to recognize knowledge generated outside the boundaries of the firm, and the amount of the knowledge that is absorbed and implemented to generate products or enhance processes [23]. To increase the absorptive capacity of a company, firms must invest in R\&D through the acquisition of highly skilled human capital and the utilization of Information and Communication Technologies (ICTs) that enable exploration of the market and competitors [31]. Start-ups are dependent on their level of absorptive capacity to be able to identify technological knowledge spillovers and the level of involvement of innovation by using knowledge spillovers as an input [23, 42]. The implementation of new technologies is dependent on the availability of a budget to conduct market research and hire or subcontract human capital to develop products, services, and conduct competitor assessment [32]. Hence, accelerator programmes can act as intermediaries that provide the ICT and technological tools to capture explicit knowledge spillovers [15, 49]. However, engagement in such programmes can be indirectly affected by economic factors, such as taxes, infrastructure and unemployment [50].

High-tech start-ups that are initially developed by highly skilled human capital possess greater opportunities to develop constant engagement with product innovation. Thus, if start-ups want to engage actively in the development of technological products and services, the decision to hire or train human capital depends on the level of technological complexity [7]. Hence, start-ups can 
decide to engage with universities and research organizations to cover the gaps in skilled human capital by e.g. receiving students as interns.

\section{METHODOLOGY}

This research employs a multi-case study approach to examine CEO perspectives on the implementation of knowledge spillovers in the early stages of High-Tech start-ups. Specifically, we explore knowledge spillover before, during and after attending incubator and accelerator programmes, and in the context of Greater London [51].

\section{A. $\quad$ Data Sampling}

Case study research stipulates that the collection of data has to be conducted until theoretical saturation and replication is obtained. This is often equated to a recommended sample of thirty participants $[52,53]$. Our unit of analysis is CEOs and co-founders that are currently part of hightech start-ups with less than ten years of operation, and that have been through an accelerator or incubator program. The selection of participants followed a non-probabilistic theoretical sampling method, selecting companies that attended independent business oriented accelerator programmes and incubators located in Greater London, UK [3, 54, 55, 56]. Accelerator and incubator programmes were used to identify and select high-tech start-ups, whilst Greater London was chosen as an ideal location to explore KSTE as this region is considered one of the main entrepreneurial ecosystems in Europe. It has one of the highest numbers of start-ups globally and a high population density of 250,000 inhabitants [54, 55].

\section{B. Data Collection and Data Analysis Procedures}

The collection of data followed a semi-structured interview research protocol, as a means of relating to initial concepts and definitions [57]. Interviews with CEOs and Co-founders of HighTech start-ups took place through face-to-face meetings, Skype and telephone calls and lasted on 
average between 45 to 90 minutes. A total of 323 email interactions from entrepreneurs led to thirty-two interview meetings. Table 1 describes the main characteristics of the participants. The interviewees were recorded, transcribed and analyzed using NVivo 11 following the widely recommended methods [53].

\section{\#\#\# INSERT TABLE 1 HERE \#\#\#}

The development of our model followed the process of theory building, through which concepts and propositions were developed from the data collected [53, 54]. As per normal procedure, the analysis involved identifying themes from interviewee responses which align with the concepts identified in the literature [58]. Specifically, The interview themes were coded using NVivo 11, and the software helped to identify patterns in the data for the formulation of propositions for the development of our explanatory model [59]. The research started with the identification of an initial set of concepts, frameworks and theories that enabled the creation of a deductive model to use as a guideline for the analysis of the data [51]. Thus, this research methodology aims to attain theoretical replication of the patterns identified across all cases in the research [60]. For that purpose, we conducted an initial identification of coding, including focus coding and analytic memos from the interview transcriptions [61]. This process enabled the creation of constructs that support the testing of the generated theoretical propositions [62]. These are discussed in the following section.

\section{FINDINGS}

The objective in this section is to uncover the actions that enable the survival and growth of startups. To facilitate the presentation of data and analysis, we created codes for each quote that were used in the analysis; these are presented in Appendix 1. The Participants of this study operate in different High-Tech industries and possess varying levels of experience, which enables the assessment and highlighting of different managerial decisions and approaches taken by CEOs and 
co-founders. As such our research examines the initial development of start-ups, taking into consideration the main events where CEOs are exposed to knowledge spillovers and how this affected the direction of the company towards product innovation and is illustrated in Figure 1 . We start by describing the point where entrepreneurs decide to initiate a new venture with an endpoint at which the company engages in the innovation of products with the market. To do so we discuss the tools and mechanisms that enable flows of knowledge spillovers and the effects that they have on each stage of the life cycle of start-ups, before the growth stage.

\#\#\# INSERT FIGURE 1 HERE \#\#\#

\section{A. Start-up}

The start of a new venture commences with the identification of an idea to develop a start-up company [1]. In our study we are able to find the motivations and sources of tacit knowledge spillovers are developed by entrepreneurs working in industry, academia, or who had created a previous start-up (SU1).

In the case of the biotechnology sector start-ups CEOs, co-founders, and board members are normally PhDs with previous experience operating in the pharmaceutical sector. The initial decision to start a new company was based on the availability of funding, academic skills, and technological knowledge. Start-ups in this sector base the valuation of their company on previous academic research, initiatives to publish papers, or from the evaluation of the idea from previous working experience in the sector (SU1, SU2). Moreover, the decision that triggers the creation of high-tech start-ups is the opportunity that entrepreneurs find in the business domain. Therefore, the quotes grouped in this section refer to "academic background" i.e., the education and training obtained from research institutions and universities. Hence, we can state that in these cases sources 
of knowledge spillovers relate to academic research that come from tacit and institutional knowledge, and the intellectual capabilities of the starting founders [16].

In contrast, we find that CEOs originating from industry initially decide to collaborate with another entrepreneur in the same industry. This is expected in the KSTE as the identification of the initial business idea comes from knowledge spillover generated from previous industrial experience. The entrepreneurs in these cases have identified gaps in the market that have not been exploited by previous institutions.

Consequently, the evaluation of business ideas can develop from two sources of knowledge; firstly, tacit knowledge spillovers, acquired from the evaluation of the idea from the experience of founders (SU3, SU4). In this case, the founders of the company can decide to receive advice from experts in the field to obtain an estimated monetary return of the business idea. The second form of evaluation comes from access to tacit and explicit knowledge spillovers that originates from the market [1]. From this perspective, the entrepreneurs seek confirmation by conducting surveys and interviews with potential customers to provide the necessary information to create the start-up and seek funding (SU5, SU6). Start-ups that identify ideas from incumbents are businesses directed towards providing services to other larger companies; therefore, knowledge spillovers used to create the company can originate from the "industrial background" and experience of the founders. Some CEOs identified that business ideas also came from their own experience and interaction with the needs of the market. This identification comes from tacit knowledge spillovers, in which the founders and co-founders start to discuss various business ideas that lead to the identification of the use of technology to provide services for larger, market-dominating organizations. The difference with the previous cases is that the entrepreneurs would decide to start interacting with the customers by creating an initial product that would enable them to understand the requirements of the market (SU7, SU8, SU9). The difference between the other two types of entrepreneurs is 
that the highest qualification held by CEOs is typically a Bachelors' degree. Some cases showed that entrepreneurs with experience in start-ups in the past would make use of their tacit knowledge to identify and confirm the market's needs, and to be able to have the required connections to set the required contracts (SU10, SU11). Hence, a source of tacit knowledge spillover is found in the “entrepreneurial background” of the founders. In these cases, entrepreneurial opportunities are identified from the experiences of the founders, and not connected to industry or academia. Therefore, we can propose the following proposition:

Proposition 1. Tacit knowledge spillovers of entrepreneur founders set the development of the business idea through the company's absorptive capacity. The development of product innovation depends on the individual alliance between the founders and co-founders and their ability to exploit knowledge spillovers from the market and start-ups.

\section{B. Incubator and Accelerator Programmes}

High-tech start-ups that decide to enter an accelerator or incubator programme initially seek to obtain guidance from experts in the industry and through mentorship [2, 45]. Entrepreneurs highlighted that successful programmes provide guidance and support from "mentorship and access to the market” (AC1, AC2). Access to such programmes enables companies to access new networks and engage with potential clients (AC3). Hence, positive feedback on accelerators and incubators is initially dependent on the rigour and credibility of the training that enables access to investment (AC4). Incubator and accelerator programmes that do not provide these services can be viewed as a poor experience that limits further engagement with customers (AC5, AC6).

The aim of incubator and accelerator programmes is to provide marketing and business support to enhance the capabilities of start-ups to enter the market. The selection of the most appropriate program depends on the type of industry that the start-up operates in, and on the strategic goals set 
for the future [2, 63]. However, it is worth noting that accelerator programmes focus primarily on providing advisory services for only a limited time period, while incubators do not have a defined end date. Based on these characteristics, start-ups that decide to be part of an incubator are centered on making use of the physical location that it provides. Incubators also provide an environment where inexperienced entrepreneurs can access advice and knowledge from more experienced entrepreneurs. Thus, entrepreneurs that have gained knowledge through networks and learning experience would be a source of entrepreneurial knowledge spillovers for companies under development (AC7, AC8).

The process of entering an accelerator program is often challenging as it requires start-ups to undertake a competitive application procedure [63]. The development of a start-up transitions from competition to collaboration and community, with a more facilitated environment that enables the exchange of knowledge presented in tacit and explicit form through the exchange of reports and videos etc. (AC9, AC10). Therefore, all types of exchange of informal and limited knowledge obtained during incubator and accelerator programmes are defined as a form of "collaboration."

On the other hand, services provided from accelerator programmes provide a “virtual entrepreneurial platform" that is used for exchanging knowledge through the transference of documents and information relating to the exposure and evolution of technological knowledge (AC11, AC12).

Start-ups often consider engaging in multiple accelerator programmes to expand their capital network and level of experience. Among the services that are most relevant to high-tech start-ups is the opportunity to gain access to one-to-one meetings with venture capitalists, potential customers, experts in the field and investors (AC13, AC14, AC15). Moreover, entrepreneurs exploit pitching events to gain access to international knowledge spillovers, to engage with an international market and to understand the requirements needed to be competitive. Accelerator 
programmes encourage the development of common projects that facilitate access and exposure to local and international markets beyond the geographical proximity of the start-up (AC16).

Therefore, it can be stated that the acquisition of knowledge spillovers from accelerators and incubators would further affect the formation of alliances and improve the absorptive capacity of start-ups [46]. Furthermore, start-ups seek to engage in accelerator programmes to create the initial documentation required to gain funding, credibility and reputation. Hence, we define "local and international market engagement” as types of opportunities that collate market knowledge spillovers obtained during incubator and accelerator programmes. We can, therefore, propose the following proposition relating to the effects that accelerator programmes have on knowledge spillover identification:

Proposition 2.1 High-tech start-ups seek access to mentors and clients. Failure to obtain these initial requests affects the initial business performance of new ventures.

Proposition 2.2 The attendance of high-tech start-ups to accelerator and incubator programmes facilitates access to markets and entrepreneurial knowledge spillovers that create the formation of partnerships and alliances. They affect the development of the startup’s absorptive capacity.

\section{Alliances and Partnerships}

Start-ups can decide to engage in the development of future partnerships through networking activities and the previous network capital of CEOs. Moreover, accelerator and incubator programmes can act as an enabler that permits start-ups to be exposed to various companies and individuals in a range of industries and possibly engage in the process of creative destruction or construction [24, 64]. Hence, the constant exposure to different types of knowledge spillovers and organizations can increase the potential to form alliances and partnerships [1, 37]. These events 
have led start-ups to initially form collaborations with customers and suppliers along the value chain. The objective in these instances is to gather feedback on how to improve the development of products or to increase the exposure of the start-up to the market (AL1, AL2, AL3). Hence, initial formal alliances to gain knowledge spillovers are defined by “customers and suppliers”.

In the case of more experienced CEOs, alliances with bigger firms are taken as a win-win situation. In this case, the benefits gained include the increased reputation of the company and the increased chances to be and remain competitive (AL4, AL5, AL6, AL7). Therefore, all formal alliances to firms are defined as forms of partnerships with incumbents that facilitate the access to knowledge spillovers and enhancement of reputation for the start-up.

Start-ups are exposed to services in accelerators and incubators that involve the development of entrepreneurial ecosystems and the development of a community [45]. Hence, such programmes enable early stage start-ups to gather entrepreneurial knowledge spillovers on how to establish the basic processes to develop the company and to gain funding. However, at this stage, start-ups would not seek further formal alliances but, would maintain an environment of informal collaboration. The reason for this is the continuous need for CEOs to engage in alliances that increase the opportunity to exchange technological knowledge to be used for innovation, or that increases the chances to survive (AL8, AL9, AL10). Thus, interactions with start-ups are centered on the process of gaining funding from investors. Therefore, we define formal alliances of startups as limited collaboration between companies to gain entrepreneurial knowledge spillovers. Exposure to networking and pitching events are used as an opportunity for start-ups to gain insights to technological knowledge spillovers from competitors. Conversely, literature has suggested that start-ups seek locations near universities to gain access to institutional knowledge spillovers and to engage in common research projects [19]. High-tech start-ups that engaged in these types of partnerships involve the inclusion of leading professors and board members of universities that 
provide funding for $\mathrm{R} \& \mathrm{D}$ to develop technological knowledge. Such collaboration typically includes internships of graduate students that provide necessary knowledge to develop product prototypes and fulfill common contracts (AL11, AL12, AL13). Hence, we define the code “universities” as alliances formed between start-ups and academic or research institutions to engage in common research projects. However, this relationship between start-ups and academia are formed from the capital network of CEOs before start-up creation. The reason for this is that universities are not aligned with the fast-pace and timing required to innovate, and do not tend to engage directly with start-ups (AL14, AL15). In this case, our discovered "barriers" exist as forms of knowledge that prevent entrepreneurs from engaging in alliances due to the perceived unjustified resources and time required to obtain value out of alliances. Therefore, we can state the following proposition regarding the relationship of knowledge spillovers in alliances:

Proposition 3. Alliances and partnerships enhance start-ups absorptive capacity through the exchange of knowledge spillovers. These exchanges of knowledge are conducted through engagement with companies and universities.

\section{Absorptive capacity}

The development of absorptive capacity refers to the ability to capture of new knowledge [27, 31]. Factors that increase the effect of absorptive capacity are the skillsets of employees and the skills the CEO has for developing innovation. Thus, it is envisaged that absorptive capacity would be initially enhanced through the experiences of an accelerator program. First, there is the unintended type of tacit and explicit knowledge spillovers that is captured from the company CEO from other entrepreneurs or individuals. In such cases, the after effect on the evaluation of knowledge is to undertake the development of a new product or strategy for the company (AB1). 
Secondly, accelerators offer continuous services as a foundation to obtain the necessary technical knowledge to be able to innovate in the market. Therefore, it can be stated that start-ups focus on the implementation of technology to satisfy the market's needs (AB2). However, the disruption on knowledge sharing, and identification and implementation towards innovation can be caused by the limited pool of technical knowledge and absorptive capacity of start-ups (AB3). Especially in the early stages, entrepreneurs seek to sell their product and obtain partnerships that facilitate the closing of deals. Start-ups focus on maintaining openness with clients to set an initial informal process of knowledge sharing.

Third, accelerator and incubator programmes affect the CEO’s allocation of R\&D in skilled human capital for the understanding of technological knowledge spillovers, and to further engage in product innovation (AB4, AB5). Start-ups decide to integrate the implementation of agile methods by assigning a technical project team focused on implementing features and the functionality of products, and to further explore entry to new markets. Thus, it can be stated that the aim of startups that are in the seed stage of their lifecycle is to capture customer knowledge spillovers destined to enhance product innovation. The development of innovation processes have been evaluated previously from the perspective of allocation of $R \& D$ budget to obtain the resources necessary to keep up with technological innovations $[1,3,18]$. Therefore, we define the theme “knowledge spillovers” as the active capture and implementation of technological and customer knowledge. The variable includes the decisions taken by founders and entrepreneurs to adapt processes and set strategic directions.

The CEOs first decision is often to increase the capacity of technological exploration through training or hiring human capital. Which approach to take can depend on the technological aim of the company. Companies might seek to hire human capital with sufficient technological expertise to replicate the use of technology and machinery seen elsewhere through the capture of knowledge 
spillovers (AB6, AB7). In addition, the R\&D budgets of start-ups is shared with other operational requirements of the company such as marketing or sales (AC8, AC9). Hence, we define "human capital” as the hired employees of the company that are engaged in R\&D activities, and engagement with the market. We find that typically one to two thirds of the R\&D budget is dedicated to the hiring of such human capital [36, 40]. High-tech start-ups are seeking to develop an initial product that enables them to conduct tests and engage in continuous product development cycles (AB10, AB11, AB12). Moreover, we find that high-tech start-ups further develop the use of ICTs to establish virtual platforms with the customers and start-ups communities from the accelerator, and search engines to constantly gather explicit knowledge spillovers (AB13. AB14, AB15). Hence, “product development" involves the exchange of tacit knowledge spillovers involved with the piloting and testing of the product with the customers. On the other hand, "virtual platforms and search engines” include all actions taken by entrepreneurs to access explicit knowledge spillovers using ICTs. Therefore, we can state the following proposition:

Proposition 4. High-tech start-ups hire skilled human capital to increase entrepreneurial absorptive capacity directed to identifying technological knowledge spillovers for use towards product innovation. The mechanisms used to access customer and public knowledge spillovers require the implementation of technological tools and search engines.

\section{E. Innovation}

The previous analysis of themes has focused on formal networks and collaboration with customers to engage in the product innovation effort in existing markets [23]. However, in many cases the strategic approach of CEOs is not to center their activities on a process of disruption, but to engage in the design and development of revolutionary, innovative products that offer a service using technological tools in unexploited markets. Hence, many start-ups aim to engage in exploiting 
technological knowledge by engaging in a constant process of open innovation and to enhance the characteristics of current products [44]. At this stage, CEOs consider that the major effect that the accelerator and incubator programmes have is on the formation of collaboration and alliances between companies. Therefore, the aim of the companies is initially to seek technological knowledge spillovers that are obtained from gaining access to a knowledge base. However, early stage CEOs, developing their first venture, point out that the activity of innovation and collaboration can disrupt and mislead the process (IN1, IN2, IN3, IN4). As a result, we could initially stipulate that the development of informal collaboration is more important than formal alliances in the early stages of a start-up. Therefore, innovation can be limited to potential "barriers" based on the current resources and development stage of the company. On the other hand, start-ups responses have defined "technology adaptation" as the process of implementing current technologies to gain a competitive edge in unexploited markets.

Start-ups that choose to engage in alliances or informal collaborations seek to establish common learning practices. Thus, start-ups end up obtaining business knowledge spillovers when setting the right strategy to engage with companies, while larger corporations purposefully use these arrangements to learn how to innovate (IN5, IN6). Consequently, the effects of increasing absorptive capacity from human capital, establishing the formation of alliances, and the resources provided from the accelerator and incubator programmes, lead to the development of product innovation, while the development of processes is enhanced through business knowledge spillovers acquired from companies [3, 65]. Hence, “process enhancement” encompasses the use of adequate implementation of knowledge spillovers during the product development cycle.

Our data suggests that the main mechanisms for engaging in the process of innovation are to conduct initial experiments using knowledge spillovers acquired from various sources in different formats. Once in development, the process requires a project team to constantly monitor timing 
and implementation to be able to get to the market efficiently and to continue cycling through the process by sharing constant information and data (IN7, IN8) [23]. To keep the innovation process alive, start-ups decide to focus most of their financial funding on these projects. However, this factor can also be considered as a major problem in the long term if it is not properly managed (IN9, IN10). Moreover, start-ups aim to continue further expanding the company by engaging with international markets, which requires further focus, not only on the speed of innovation, but also the quality of the products produced (IN11, IN12). Therefore, we can propose that our dependent variable for the conceptual model is product innovation. Hence, innovation is heavily dependent on the "funding" of R\&D to continuously develop prototypes that enable the testing of the product in local and international markets.

\section{DISCUSSION}

The analysis above identifies the variables for our conceptual model and provides an insight into knowledge spillover exposure in high-tech start-ups. In this section, we address the type of knowledge spillovers captured and implemented by start-ups as was illustrated in Figure 1 . The identified knowledge spillovers take into account the classifications of tacit and explicit knowledge [33], with the different types of knowledge spillover being involved in every stage of the start-up, flowing informally and being unattached to financial requirements.

First, the initial evaluation of the business idea comes from the shared experiences of the company founders. However, the type of knowledge spillovers captured from industry or academia will set the conditions to decide whether the start-up requires further engagement with alliances or whether it might rely on individual capital networks to gain funding and future contracts [40]. In the case of academia, the identification of the idea emerges from research conducted by academics. On this basis, entrepreneurial ideas which arise from academic research are considered a form of 
institutional knowledge spillover. However, entrepreneurs coming from industry rely on sources of technical knowledge spillovers to identify gaps in the market and customer needs. In these cases, entrepreneurs decide to break the chain and create a new company $[5,10]$. In both cases, entrepreneurs may decide to evaluate their business idea through meetings with experts or by issuing surveys and interviews to potential customers. These can be both a form of local or international market knowledge spillover. There is also a third initial form of entrepreneurial knowledge spillover which sees entrepreneurs identifying a gap based entirely on their ability to identify a missing product or service that has not been introduced to the market [1]. In these cases, start-ups prefer to engage the market by developing an initial product that can be presented to potential customers.

Next, Start-ups exploit their absorptive capacity to increase their explorative discovery of entrepreneurial opportunities [63]. Here, during the development of the start-up, the CEO decides to enter an accelerator or incubator program for access to business knowledge spillovers from other entrepreneurs (accelerators). The main effect of this is the increase in capability of the company to gather funding and to set strategic goals. Aligned with this development process, CEOs have the opportunity to be exposed to technological knowledge spillovers from competitors at pitching events and can decide to change their main product features. Additionally, accelerators enable virtual platforms to be created that can be used after the end of the accelerator program to access pools of knowledge during the innovation process [43]. Consequently, start-ups would decide to engage in alliances and partnerships with other companies and academic institutions. Hence, institutional knowledge spillovers from universities are developed through common projects and research conducted between start-ups and leading academics in the field [8, 19]. CEOs can also establish partnerships with companies close to their value chain through exchanges of 
information to keep enhancing the internal processes and to obtain technological and business knowledge spillovers from alliances.

High-tech start-ups decide to increase their level of absorptive capacity by hiring skilled human capital and brings technological knowledge spillovers aimed at identifying entrepreneurial opportunities [27]. Further information capturing is obtained through the utilization of virtual platforms and ICTs that facilitate access to customer and supplier knowledge spillovers, while the use of internet and search engines can gather public and institutional knowledge spillovers in the form of academic research and other web-based content. Finally, start-ups can decide to expand by continuing to use all sources of knowledge until they pass to the growth stage of their lifecycle, where the company starts engaging with international markets and starts the development of a scalable product. Therefore, we can set the following proposition as follows:

Proposition 5.1. Tacit and explicit knowledge spillovers, from the previous experiences of the CEO and engagement with the market and industry experts, enable the evaluation of initial business ideas that trigger the creation of start-ups.

Proposition 5.2. Tacit and explicit knowledge spillovers captured from partnerships and alliances, through virtual platforms and search engines, enable continuous product innovation.

\section{CONCLUSIONS}

This paper proposes a conceptual model to identify the effects of knowledge spillovers in start-up development and product innovation. By stating propositions and identifying associated variables, this research has established a grounding for further research on the effects of knowledge spillovers at the individual entrepreneur level [22]. Although the literature is dominated by the assumption that knowledge spillovers are automatically captured by entrepreneurs and companies, our findings 
suggest that the initial characteristics of CEOs and co-founders have a great impact on deciding which type of knowledge spillovers are absorbed during initial venture conceptualization and during the seed stage of the start-up [3, 20, 45]. Although the KSTE assumes that geographic proximity is a mandatory enabler to the initial capture of knowledge spillovers, our findings suggest that entrepreneurs access knowledge through collaborations, partnerships and information that can also be obtained through virtual platforms and ICTs, which nullifies the effects of distance between the sources of knowledge spillovers and start-ups.

This paper has further provided an initial analysis of how knowledge spillovers are not limited to physical proximity but also exist in cognitive spaces [11, 33]. The KSTE clearly states that geographical proximity to sources of knowledge, such as universities and companies, facilitates an initial cluster of knowledge [11, 29]. Our findings suggest that it is the initial network capital of the founders that grants access to tacit knowledge spillovers and promotes the creation of the new venture [26]. Furthermore, we establish that, aside from universities and companies, interactions with entrepreneurs are a major source of local entrepreneurial knowledge which is exploited in creating the company [35]. The company founders go on to seek tacit or explicit knowledge spillovers to validate their business idea [1, 31]. In doing so they employ mechanisms to remove entrepreneur uncertainty such as conducting market research, by testing the product, analyzing interviews or surveys, and gaining insights through one-to-one discussions with industry experts. In addition, our model sheds further light on the available sources of knowledge spillovers and the mitigating impact on start-ups of accelerator and incubator programmes. Our findings suggest that general business knowledge spillovers are shared among entrepreneurs during their accelerator programme, which builds a community that can be harnessed as a pool of tacit and explicit knowledge spillovers, forming a previously overlooked entrepreneurial ecosystem [43, 55]. However, the findings also suggest that high-tech entrepreneur that have acquired sufficient 
network capital and a high valuation of their business idea, often seek to bypass the entrepreneurial opportunities that can be attained during accelerator and incubator programmes. In addition, hightech start-ups frequently decide to engage in partnerships or further alliances with companies and customers that enable them to gain business and technological knowledge spillovers, as well as reputation to gain contracts and further funding. Moreover, collaboration gives constant transmission of tacit knowledge spillovers and is used to test products via continuous interactions enhancing the product development lifecycle. Also new is the observation that a selection of technical knowledge spillovers from alliances, collaborations and international customers, is transferred through virtual platforms and start-up communities [40, 66]. High-tech start-ups also use these various technological platforms and search engines to access explicit knowledge spillovers from the public domain [23]. These forms of knowledge transition break the limitations of geographical proximity between companies and entrepreneurs.

This paper has provided evidence that high-tech start-ups in the early stages of start-up development focus their endeavours on product innovation, rather than business formation. The emphasis of companies is to allocate funding to $R \& D$ to hire human capital with the required technological knowledge to exploit virtual platforms and search engines [25, 39]. The primary indicator at this stage of development is engagement with customers in local or international environments. This research has illustrated that start-ups focus their attention on using current technologies to innovate by providing products and services that cover a gap in the market. They will then continue innovating until a new product is developed and introduced in the market. The results suggest that once a start-up has engaged with international markets, there is an increased growth that can lead to the transition from the seed stage to the growth stage $[1,3]$.

This research also offers critical insights for policymakers on the roles and effects that accelerator and incubator programmes have on high-tech start-ups. First, incubators and accelerators are 
important in delivering specialized knowledge and so such programmes must aim to securing funding for and assist in the economic growth of start-ups [45, 21]. Hence, governmental policies should enforce processes that support funding for companies and track the subsequent performance of companies [21]. Growth indicators include the increase of hired human capital, investment in R\&D by the company on technology, and formal entry to the market. Second, selection criteria should focus on specific criteria for companies attending the accelerator programmes. For instance, programmes have to take into account the regions, technological background, and the stage of the company [3]. Our data suggests that companies in the growth stage are heavily focused on using virtual technologies to gain technological knowledge for product innovation. Further effects require exploration to consider how to maximize the exposure of high-tech start-ups in the seed stage to international markets [1].

Finally, this research has some limitations. One major limitation is that the primary data comes from multiple case studies of high-tech start-ups that attended an incubator or accelerator program in Greater London, UK, and so findings may differ from other regions worldwide. However, we have attempted to reduce the limitations of a possibly stratified sample by taking interviews from multiple CEOs and co-founders, providing a variety of perspectives that enable the evaluation of perceptions towards knowledge spillovers. As such we have illustrated the differences and similarities in the decisions taken by entrepreneurs to develop their start-ups during the early stages of the lifecycle. We are satisfied with the analysis and collection of data, which was confirmed as we reached the point of theoretical saturation and replicability [52, 67]. Further research should consider generalizing these findings with confirmatory factor analysis to evaluate the statistical significance of the concepts identified. 


\section{ACKNOWLEDGEMENTS}

The authors would like to thank the 32 Chief Executive Officers and Co-founders who took part in this research for their valuable comments and contributions. 


\section{REFERENCES}

[1] C. Cantù, "Entrepreneurial knowledge spillovers discovering opportunities through understanding mediated spatial relationships,” Ind. Mark. Manag., vol. 61, pp. 30-42, 2017.

[2] S. Cohen, C. Bingham, C. Hill, and B. Hallen, "Why are Some Accelerators More Effective? Bounded Rationality and Venture Development,” Acad. Manag. Annu. Meet. Proc., 2017.

[3] M. von Zedtwitz, "Classification and management of incubators: aligning strategic objectives and competitive scope for new business facilitation," Int. J. Entrep. Innov. Manag., vol. 3, no. 1/2, p. 176, 2003.

[4] H. Renski, "New Firm Entry, Survival, and Growth in the United States: A Comparison of Urban, Suburban, and Rural Areas,” J. Am. Plan. Assoc., vol. 4363, no. June, pp. 60-77, 2017.

[5] A. Tsvetkova, "Innovation, Entrepreneurship, and Metropolitan Economic Performance: Empirical Test of Recent Theoretical Propositions,” Econ. Dev. Q., vol. 29, no. 4, pp. 299316, Nov. 2015.

[6] D. Audretsch, D. Dohse, and A. Niebuhr, "Cultural diversity and entrepreneurship: a regional analysis for Germany.,” Ann. Reg. Sci., vol. 45, no. 1, pp. 55-85, Aug. 2010.

[7] E. Stam, "Knowledge and Entrepreneurial Employees: A Country-Level Analysis," Small Bus. Econ., vol. 41, no. 4, pp. 887-898, Dec. 2013.

[8] D. B. Audretsch and E. E. Lehmann, "Does the Knowledge Spillover Theory of Entrepreneurship Hold for Regions?,” in Entrepreneurship and Regional Development, Z. J. Acs, Ed. Unlisted: Elgar Reference Collection. International Library of Entrepreneurship, vol. 16. Northampton, Mass. and Cheltenham, U.K.: Elgar, 2010, pp. 433-444.

[9] J. A. Schumpeter, Capitalism, socialism, and democracy. New York: Harper, 1950.

[10] D. B. Audretsch and P. E. Stephan, "Knowledge Spillovers in Biotechnology: Sources and Incentives," in Entrepreneurship, Innovation and Economic Growth, D. B. Audretsch, Ed. Max Planck Institute of Economics and IN U: Cheltenham, U.K. and Northampton, Mass.:, 2006, pp. 70-80.

[11] D. B. Audretsch and E. E. Lehmann, "Does the Knowledge Spillover Theory of Entrepreneurship hold for regions?,” Res. Policy, vol. 34, no. 8, pp. 1191-1202, Oct. 2005.

[12] K. J. Arrow, "Economic Welfare and the Allocation of Resources for Invention,” Readings Ind. Econ., pp. 219-236, 1972.

[13] J. Jacobs, Economy of cities. New York, NY : Vintage Books, 2016.

[14] J. Korosteleva and M. Belitski, "Entrepreneurial dynamics and higher education institutions in the post-Communist world,” Reg. Stud., vol. 51, no. 3, pp. 439-453, 2017.

[15] F. Lasch, F. Robert, and F. Roy, "Regional determinants of ICT new firm formation.," Small Bus. Econ., vol. 40, no. 3, pp. 671-686, Apr. 2013.

[16] M. E. Porter, "Location, Competition, and Economic Development: Local Clusters in a Global Economy,” Econ. Dev. Q., vol. 14, no. 1, pp. 15-34, 2000.

[17] P. M. Romer, “Endogenous Technological Change,” J. ofPolitical Econ., vol. 98, no. 5, pp. S71-S102, 1990.

[18] A. Montoro-Sánchez, M. Ortiz-de-Urbina-Criado, and E. M. Mora-Valentín, "Effects of knowledge spillovers on innovation and collaboration in science and technology parks," $J$. Knowl. Manag., vol. 15, no. 6, pp. 948-970, 2011.

[19] N. Ghio, M. Guerini, and C. Rossi-Lamastra, "University knowledge and the creation of innovative start-ups: an analysis of the Italian case,” Small Bus. Econ., vol. 47, no. 2, pp. 293-311, 2016. 
[20] D. B. Audretsch, D. F. Kuratko, and A. N. Link, "Making sense of the elusive paradigm of entrepreneurship,” Small Bus. Econ., vol. 45, no. 4, pp. 703-712, 2015.

[21] S. R. Sedita, R. Apa, T. Bassetti, and R. Grandinetti, "Measuring the effect of business incubators on the innovation performance of start-ups,” Acad. Manag. J., 2017.

[22] M. Stuetzer, D. B. Audretsch, M. Obschonka, S. D. Gosling, P. J. Rentfrow, and J. Potter, "Entrepreneurship culture, knowledge spillovers and the growth of regions," Reg. Stud., no. March, pp. 1-11, 2017.

[23] M. Nieto and P. Quevedo, "Absorptive capacity, technological opportunity, knowledge spillovers, and innovative effort,” Technovation, vol. 25, no. 10, pp. 1141-1157, 2005.

[24] R. Agarwal, D. Audretsch, and M. Sarkar, "Knowledge spillovers and strategic entrepreneurship,” Strateg. Entrep. J., vol. 4, no. 4, pp. 271-283, 2010.

[25] M. Vivarelli, “Are all the potential entrepreneurs so good?,” Small Bus. Econ., vol. 23, no. 1, pp. 41-49, 2004.

[26] C. S. Hayter, “Conceptualizing Knowledge-Based Entrepreneurship Networks: Perspectives from the Literature,” Small Bus. Econ., vol. 41, no. 4, pp. 899-911, Dec. 2013.

[27] H. Qian and H. Jung, "Solving the knowledge filter puzzle: absorptive capacity, entrepreneurship and regional development,” Small Bus. Econ., vol. 48, no. 1, pp. 99-114, Jan. 2017.

[28] Z. J. Acs, P. Braunerhjelm, D. B. Audretsch, and B. Carlsson, "The Knowledge Spillover Theory of Entrepreneurship," in Institutional Entrepreneurship, M. Henrekson and T. Sanandaji, Eds. George Mason U: Elgar Research Collection. International Library of Entrepreneurship, vol. 24. Cheltenham, U.K. and Northampton, Mass.: Elgar, 2012, pp. 137-152.

[29] A. Colombelli, "The impact of local knowledge bases on the creation of innovative start-ups in Italy,” Small Bus. Econ., vol. 47, no. 2, pp. 383-396, 2016.

[30] B. Verspagen, "Measuring Intersectoral Technology Spillovers: Estimates from the European and US Patent Office Databases,” Econ. Syst. Res., vol. 9, no. 1, pp. 47-65, 1997.

[31] H. Qian and Z. J. Acs, "An Absorptive Capacity Theory of Knowledge Spillover Entrepreneurship,” Small Bus. Econ., vol. 40, no. 2, pp. 185-197, Feb. 2013.

[32] M. Fritsch and J. Changoluisa, "New business formation and the productivity of manufacturing incumbents: Effects and mechanisms,” J. Bus. Ventur., vol. 32, no. 3, pp. 237-259, 2017.

[33] I. Nonaka, R. Toyama, and N. Konno, "SECI, Ba and Leadership: A Unified Model of Dynamic Knowledge Creation,” Long Range Plann., vol. 33, no. 1, pp. 5-34, 2000.

[34] D. B. Audretsch and M. Vivarelli, "Firms size and R\&D spillovers: Evidence from Italy," SMALL Bus. Econ., vol. 8, no. 3, pp. 249-258, Jun. 1996.

[35] R. Kauffman, S.-C. Ho, and T.-P. Liang, "Internet-based selling technology and e-commerce growth: a hybrid growth theory approach with cross-model inference," Inf. Technol. Manag., pp. 409-429, 2011.

[36] A. Spithoven and P. Teirlinck, "Internal capabilities, network resources and appropriation mechanisms as determinants of R\&D outsourcing,” Res. Policy, vol. 44, no. 3, pp. 711-725, 2015.

[37] C. Shu, C. Liu, S. Gao, and M. Shanley, “The Knowledge Spillover Theory of Entrepreneurship in Alliances,” Entrep. Theory Pract., vol. 38, no. 4, pp. 913-940, 2014.

[38] D. B. Audretsch and E. E. Lehmann, "Does the knowledge spillover theory of entrepreneurship hold for regions?,” Res. Policy, vol. 34, no. 8, pp. 1191-1202, 2005.

[39] E. Santarelli and M. Vivarelli, "Entrepreneurship and the process of firms' entry, survival 
and growth,” Ind. Corp. Chang., vol. 16, no. 3, pp. 455-488, 2007.

[40] R. Narula and G. D. Santangelo, "Location, collocation and R\&D alliances in the European ICT industry,” Res. Policy, vol. 38, no. 2, pp. 393-403, 2009.

[41] S. Amoroso, D. B. Audretsch, and A. N. Link, "Sources of knowledge used by entrepreneurial firms in the European high-tech sector,” Eurasian Bus. Rev., pp. 1-16, 2017.

[42] R. Agarwal, D. B. Audretsch, and M. B. Sarkar, "Knowledge Spillovers and Strategic Entrepreneurship,” Strateg. Entrep. J., vol. 4, no. 4, pp. 271-283, 2010.

[43] D. B. Audretsch and M. Belitski, "Entrepreneurial ecosystems in cities: establishing the framework conditions,” J. Technol. Transf., vol. 42, no. 5, pp. 1030-1051, 2017.

[44] P. Hausberg and S. Korreck, "Business Incubators and Accelerators: Review and Research Agenda,” Acad. Manag. Annu. Meet. Proc., 2017.

[45] B. Mrkajic, "Business incubation models and institutionally void environments," Technovation, vol. 68, no. July, pp. 44-55, 2017.

[46] K. Nicolopoulou, M. Karatas, C. Vas, and M. Nouman, “An incubation perspective on social innovation:the London Hub-a social incubator,” R\&D Manag., vol. 47, no. 3, pp. 368-384, 2016.

[47] R. B. Bouncken and S. Kraus, "Innovation in knowledge-intensive industries: The doubleedged sword of coopetition,” J. Bus. Res., vol. 66, no. 10, pp. 2060-2070, 2013.

[48] C. S. Hayter, "Conceptualizing knowledge-based entrepreneurship networks: Perspectives from the literature,” Small Bus. Econ., vol. 41, no. 4, pp. 899-911, 2013.

[49] A. Spithovenm and M. Knockaert, “Technology intermediaries in low tech sectors: The case of collective research centres in belgium,” Innov. Manag. Policy Pract., vol. 14, no. 3, pp. 375-387, 2012.

[50] F. Lasch, F. Robert, and F. Le Roy, "Regional determinants of ICT new firm formation," Small Bus. Econ., vol. 40, no. 3, pp. 671-686, 2013.

[51] S. Merriam, Qualitative research : a guide to design and implementation, Fourth edition. 2016.

[52] R. Thorpe and R. Holt, The Sage dictionary of qualitative management research. Los Angeles : Sage Publications, 2008.

[53] M. N. K. Saunders, P. Lewis, and A. Thornhill, Research methods for business students, Seventh edition. 2016.

[54] R. B. (Robert B. Burns, Introduction to research methods, 4th ed. Thousand Oaks Ca: SAGE, 2000.

[55] D. B. Audretsch, M. Belitski, and S. Desai, "Entrepreneurship and economic development in cities,” Ann. Reg. Sci., vol. 55, no. 1, pp. 33-60, 2015.

[56] K. M. Eisenhardt, "Building Theories from Case Study Research Published by: Academy of Management Stable URL: http://www.jstor.org/stable/258557 Linked references are available on JSTOR for this article : Building Theories from Case Study Research," vol. 14, no. 4, pp. 532-550, 2016.

[57] J. W. Creswell and V. L. Plano Clark, Designing and conducting mixed methods research, Third edition. 2018.

[58] P. Bazeley, Qualitative data analysis: practical strategies, Repr. Los Angeles: Sage Publications, 2014.

[59] M. N. K. Saunders, P. Lewis, and A. Thornhill, Research methods for business students, Seventh ed. 2016.

[60] R. K. Yin, Case study research : design and methods. Sage Publications, 2003.

[61] P. Bazeley, Qualitative data analysis: practical strategies, Repr. Los Angeles: Sage 
Publications, 2014.

[62] M. E. Gräbner and K. M. Eisenhardt, "Theory building from cases: opportunities and challenges,” Acad. Manag. J., vol. 50, no. 1, pp. 25-32, 2007.

[63] C. Pauwels, B. Clarysse, M. Wright, and J. Van Hove, “Technovation Understanding a new generation incubation model : The accelerator," vol. 51, pp. 13-24, 2016.

[64] R. Dyerson and A. Pilkington, "Gales of creative destruction and the opportunistic incumbent: The case of electric vehicles in California,” Technol. Anal. Strateg. Manag., vol. 17, no. 4, pp. 391-408, 2005.

[65] B. Mrkajic, "Business incubation models and institutionally void environments," Technovation, vol. 68, no. September, pp. 44-55, 2017.

[66] D. Audretsch and A. Link, "Embracing an Entrepreneurial Ecosystem: An Analysis of the Governance of Research Joint Ventures,” UNCG Econ. Work. Pap., no. August, 2017.

[67] J. W. Creswell, Research design : qualitative, quantitative, and mixed methods approaches, 4th ed. Los Angeles: SAGE Publications, 2014. 


\section{Figure 1: Conceptual Model}

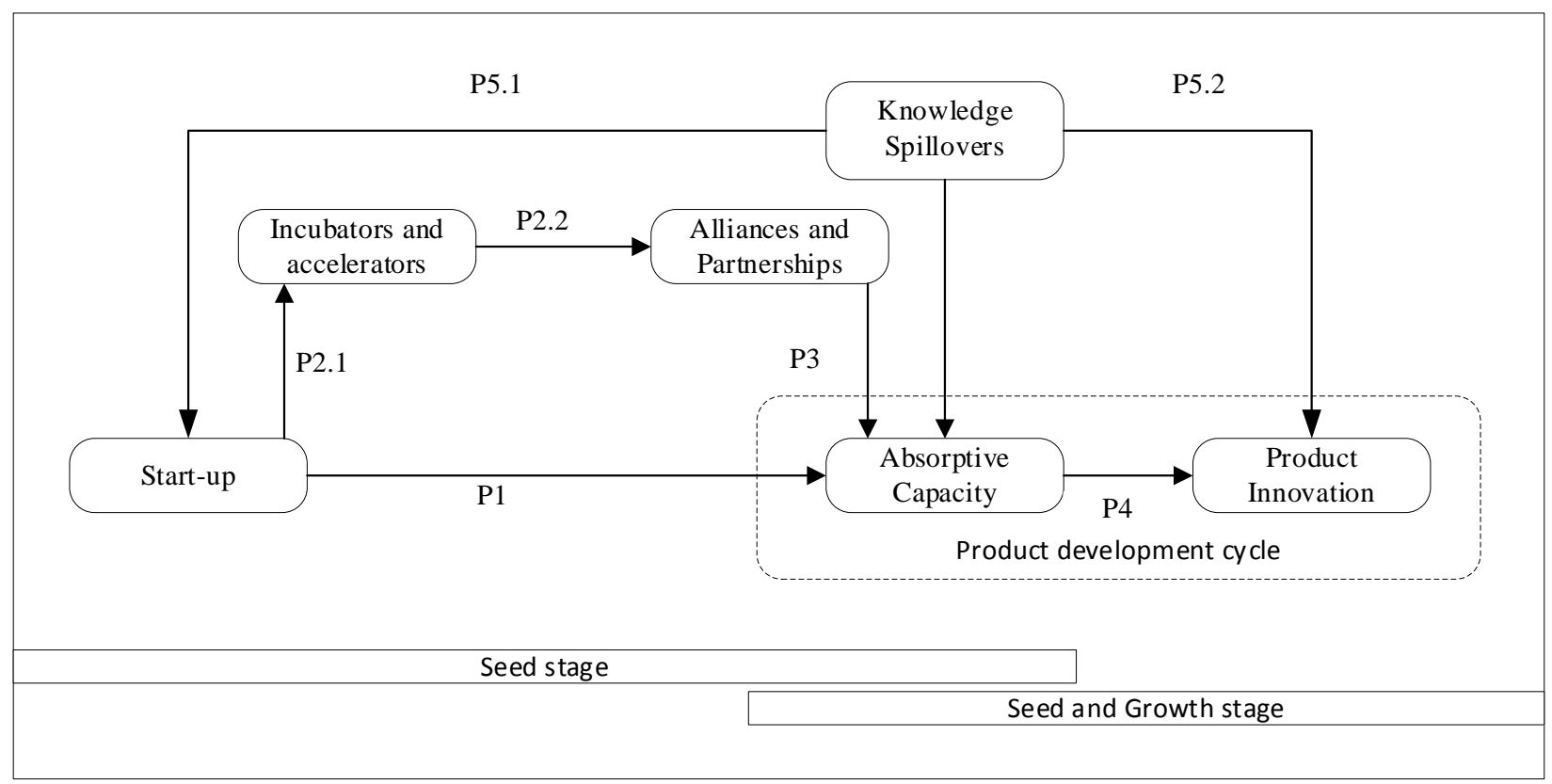


Table 1: Characteristics of the interviewees

\begin{tabular}{|c|c|c|c|c|c|c|}
\hline Interview & Nationality & Age & Highest Qualification & $\begin{array}{l}\text { Number of } \\
\text { employees }\end{array}$ & Job position & $\begin{array}{c}\text { Years of } \\
\text { operation }\end{array}$ \\
\hline 1 & Greek & 36 & Ph.D. & 4 & Chief Executive Officer & 7 \\
\hline 2 & British & 50 & Ph.D. & 26 & Vice president of COC & 2 \\
\hline 3 & British & 55 & Ph.D. & 57 & Chief Executive Officer & 6 \\
\hline 4 & British & 68 & BA Business Manager & 12 & Executive Chairman & 12 \\
\hline 5 & British & 60 & MBA & 24 & Chief Executive Officer & 2 \\
\hline 6 & $\begin{array}{l}\text { Canadian, } \\
\text { Irish }\end{array}$ & 34 & MBA & 50 & Chief Executive Officer & 3 \\
\hline 7 & British & 35 & Ph.D. candidate & 1 & Chief Executive Officer & 2 \\
\hline 8 & French & 37 & Master's degree & 15 & Chief Executive Officer & 3.5 \\
\hline 9 & British & 31 & Doctorate in medicine & 8 & Operations Director & 3 \\
\hline 10 & British & 44 & BA Science & 32 & Chief Executive Officer & 3.5 \\
\hline 11 & French & 38 & Master's degree in science & 7 & Chief Executive Officer & 2 \\
\hline 12 & British & 39 & Master's degree & 80 & Chief Executive Officer & 7 \\
\hline 13 & Indian & 25 & Master's degree MIT & 14 & Chief Executive Officer & 3 \\
\hline 14 & Lebanese & 34 & Bachelor's degree & 9 & Chief Executive Officer & 5 \\
\hline 15 & Irish & 24 & Bachelor's degree & 16 & $\begin{array}{l}\text { Customer Engagement } \\
\text { Manager }\end{array}$ & 3 \\
\hline 16 & British & 29 & Bachelor's degree & 5 & $\begin{array}{l}\text { Chief Operations } \\
\text { Officer }\end{array}$ & 2 \\
\hline 17 & American & 43 & Master's degree & 11 & Chief Executive Officer & 2.5 \\
\hline 18 & Danish & 34 & Master's degree & 9 & Chief Executive Officer & 2 \\
\hline 19 & Greek & 34 & Master's degree & 15 & Chief Executive Officer & 6 \\
\hline 20 & British & 50 & Master's degree & 30 & Chief Executive Officer & 15 \\
\hline 21 & $\begin{array}{l}\text { British, } \\
\text { Canadian } \\
\end{array}$ & 41 & $\begin{array}{l}\text { Bachelor's degree, } \\
\text { engineering }\end{array}$ & 5 & Chief Executive Officer & 4 \\
\hline 22 & Canadian & 28 & Bachelor's degree & 8 & Chief Executive Officer & 2 \\
\hline 23 & British & 28 & Bachelor's degree & 9 & Chief Executive Officer & 4 \\
\hline 24 & British & 49 & Ph.D. & 4 & Chief Executive Officer & 4 \\
\hline 25 & Italian & 34 & Master's degree & 5 & Chie Executive Officer & 3 \\
\hline 26 & Australian & 47 & Bachelor's degree & 65 & Chief Executive Officer & 3.3 \\
\hline 27 & British & 45 & Bachelor's degree & 19 & Chief Executive Officer & 3 \\
\hline 28 & British & 39 & MBA & 4 & Chief Executive Officer & 3.5 \\
\hline 29 & British, Uzbek & 27 & Bachelor's Degree & 2 & Chief Executive Officer & 2 \\
\hline 30 & Israeli & 42 & MBA & 25 & Chief Executive Officer & 3 \\
\hline 31 & British & 42 & MBA & 11 & Chief Executive Officer & 4 \\
\hline 32 & British & 43 & MBA & 27 & Chief Executive Officer & 4 \\
\hline
\end{tabular}




\section{Appendix 1: Relevant themes and quotations}

\begin{tabular}{|c|c|c|c|c|}
\hline Themes & Theme codes & Relevant Quotes & Interview & Code \\
\hline \multirow[t]{11}{*}{ Start-ups } & $\begin{array}{l}\text { Academic } \\
\text { Background }\end{array}$ & $\begin{array}{l}\text { So this is knowledge that we created, so it comes internally the establishment of this company was based on new knowledge from two or } \\
\text { three individuals from the scientific family. So, that's where the intellectual knowledge comes from so we used the initial founding } \\
\text { knowledge, and then we develop, but we rarely take additional key knowledge from outside. }\end{array}$ & 2 & SU1 \\
\hline & & $\begin{array}{l}\text { For example the glucose sensor, we know from the gatherings that there are two or three groups working on similar ideas, but differently. So } \\
\text { you also know that no one has the product yet. That is only in the research and development stage, so you can gather information on the } \\
\text { status. }\end{array}$ & 1 & SU2 \\
\hline & $\begin{array}{l}\text { Industrial } \\
\text { background }\end{array}$ & $\begin{array}{l}\text { It was an idea of my cofounder --- he was creative director for many T.V. stations, and he realized that a lot of the trailers that he and his team } \\
\text { created never got out, so it is a waste of work. He said why don't we create a tech platform where the users are on a mobile base, used with } \\
\text { tablets, ---- we presented the idea to senior vice president of ---------, and within } 10 \text { minutes he validated the idea and was sold. He also said } \\
\text { he would pay as well for the development. }\end{array}$ & 18 & SU3 \\
\hline & & $\begin{array}{l}\text { We knew in } 2014 \text { that cybersecurity was going to be big according to market trends. We are cybersecurity experts for years so we know it } \\
\text { was important etc. so we decided when we founded the company to focus on that kind of topic without really knowing the value proposition. } \\
\text { And what we do for almost one year is conduct interviews with possible customers because at that time we had nothing to sell. }\end{array}$ & 21 & SU4 \\
\hline & & $\begin{array}{l}\text { our first step coming from cybersecurity we are trying to develop a device that would help us to maintain our identity.---We Did research } \\
\text { and interviews to validate our idea the value of the ----- if there was an actual demand for such service, the results were positive and } \\
\text { encouraged us to go forward. And with the investors, we said: OK. Let's give it a try. }\end{array}$ & 25 & SU5 \\
\hline & & $\begin{array}{l}\text { I saw the opportunity to build a product in technology that would make a difference to a lot of people.... worked in the industry for large } \\
\text { companies, so I saw the need forehand, head of sales operations mostly. Within my position, it was very clear that the need was there. } \\
\text { I looked at the number of people affected by the problem, the revenue from the number of transactions; I can make the market size on base of } \\
\text { the people that have this need. }\end{array}$ & 32 & SU6 \\
\hline & $\begin{array}{l}\text { Entrepreneurial } \\
\text { background }\end{array}$ & $\begin{array}{l}\text { I got together with my co-founder, we both shared experiences of how our used cars caused problems, and at that point, the idea was born that } \\
\text { we wanted to try free trust for a used car market. That is how it came about. }\end{array}$ & 9 & SU7 \\
\hline & & $\begin{array}{l}\text { We saw a gap in the market. We saw ------ residential apartments in London, and we thought that we could pitch this value and get a profit } \\
\text { enabling them with high-quality furniture and let large corporate travelers use them as an alternative to a hotel. } \\
\text { We looked at the supply-demand chart in key cities, looked at the time required to set up --- we looked at the rise of ---- and using these three } \\
\text { key models judge where the price. }\end{array}$ & 10 & SU8 \\
\hline & & $\begin{array}{l}\text { When I went to the university I saw it was an issue to get tickets; there was no efficiency I had friend that run events and sometimes they } \\
\text { could not find a printer, So I said } * * * * \text { I will do it myself. So I got a business going and strived to be as efficient as possible... so anyone } \\
\text { could buy a ticket, you could do it on your phone, and then the ticket company will charge you. After that, it grew and grew and grew. }\end{array}$ & 23 & SU9 \\
\hline & & $\begin{array}{l}\text { We provide image-tracking solutions for the diamond industry, for the market, we go to a ---platform to enable those diamonds to be tracked, } \\
\text { so customers, when they purchase a diamond, know where the diamond comes from. We use blockchain --- got a contract for artificial } \\
\text { intelligence to be able to identify and track a diamond ---. } \\
\text { The diamond industry is a five-hundred-year-old industry it has some mass challenges that represent billions of dollars of challenges ----- } \\
\text { slice ---and we knew you had to combine different technologies to be able to provide a different way of trade. }\end{array}$ & 26 & SU10 \\
\hline & & $\begin{array}{l}\text { One colleague lived in Canada, and he needed internet to his house, he lived in the countryside. And this guy came along and installed a ------ } \\
\text { - station on his house that transmitted the internet signal about } 10 \text { miles. That got him thinking: where is the only place that you can't get an } \\
\text { internet connection? On trains. So they did some tests with this technician guy who came to do the trial, and so we did an initial trial which } \\
\text { worked. So the first project we did was we managed to persuade --------- to do a trial, ---- I made some of the IT in my workshop, and } \\
\text { some of it is still around. Then we won huge contracts like Dutch Trains, a } 30 \text { million pound contract, then ----, a lot of U.K. business } \\
\text { projects around the world, and one of the things that really helped us, as I set up a deal with one of our main suppliers.....rail cables and } \\
\text { antennae. }\end{array}$ & 4 & SU11 \\
\hline
\end{tabular}


I think they are great, all the ones I have been involved in have had a very rigorous curriculum, ----- I think that every entrepreneur should attend sessions where he is comfortable, and I also think that having a mentor is also useful, you can hold their hand while they are in the arogram, so the importance is that it helps you get your first customer, your first case study, and that is where I think those programs are very useful.

I find this difficult at the moment, ------ has helped me a lot, they are doing something interesting and are working hard to do it, I don't have any other opportunities to meet them, because I don't know where just I would meet them, so like if you come to London from a different country or a different continent and you want to start a company here, and you don't have a network, it is going to be EXTREMELY hard.

I think there is a very big difference between a good and a not so good accelerator, some have really great mentors, access to investment, are very focused on how they form and train their start-ups, and then you have these very many informal programs that do not have. Often their It has not changed. I will tell anybody that these programs should be avoided at all costs. It distracts you from the important things ----- for developing survival skills because , you spend a lot of time on theory focusing on stuff that is not really ---- ., and developing things that are only on books and you can't execute it, and you wind up working for someone else because nobody has the clue to what the market really

needs.
I think you have got to have a little experience, Microsoft --- I recognize that. I think I realized that It is also good to get a fresh perspective. I did not have any answers --- training it was just good to be in an environment. But I think that those accelerations are what you make of it, you know they are an industry now, and most of it is ******. They are taking advantage of young people that do not have any real-world
experience.

Again, in this part of the incubator, we aren't really active. Also happens that this particular incubator is more focused as a landlord, but not as much as a collaborator with other CEOs. Does not work as an accelerator--------, but these are outside the incubator, so they are organized independently.

I am very well into collaborating ------ to assist them; we are not collaborative, we're just very focused on what we have to do, and willing to help others if we can, in a very precise fashion.

We had very structured days, our time it was very well managed, we had to do weekly reports, weekly videos.

I'd say my general thought is that incubators if they are run well, are very helpful, a place for start-ups and new CEOs to meet. So I think it's a very effective technique, for knowledge transfer, for networking, for stimulating business structures.

We were competing among entrepreneurs --- build relationships because they had been through the process before it was challenging because you would pitch in front of 500 investors --- in Berlin or Paris or London, so the whole experience was ---- challenging and helped us build some connections we would not have built otherwise.

\begin{tabular}{l}
\hline Virtual \\
entrepreneurial \\
platforms
\end{tabular}

so it is a key part of what we do a stack channel were we share with the whole company articles that are important to read or books so that type of personal development I am doing for investment.

Whenever I need to learn or have a question, ----------- has a network community called --------- where you can find anything in the ---------- community. Then the message will be sent to all the founders quickly. It is extremely valuable for all types of information.

During the program, we had to be there three days a week, and most days they would bring in people for us to meet. They'd be marketing

engagement

So it was a very good opportunity to start in Germany at an early stage, we were only six months old and had done various activities

understanding French requirements, but as we are in England ----reach the requirements of the German market, so we said we do not want it France we want it in Germany. We have program manages

Getting to -------------, they are the biggest business to business --- customer in a software company. They were a very useful partner for us, and I had just come back from Seattle (touch wood) rolling out an education program. 
We do not really have suppliers; however, but the knowledge we get is feedback from our customers occasionally connections they also

Firms Yeah so we have a partnership with our data department ---- so we share industry information all the time. ---- and we that for product or time decisions.

We do, we have quite a lot of partnerships which are pretty important for us, We work with guys that have 7 or 8 ---- on their list, and we work on their hospitality tablet, so we are small and don't have a jet team, it makes sense to work with a company that is larger in a

Very important for us because a great part of us is in partnerships, this has been very useful for us, surely if you can build partnerships where both parties have something to gain if only one is gaining it will break. But if both parties have gains you have to have an alliance; the market is very competitive. They have to have at least a department that has the same industry. Otherwise, there is no value in that alliance.

Alliances are good for young tech companies to gain credibility for customers. ----- if you want you can buy ---- from --------- people tend to think "well if they work with this guy, it is good" it is important, we are targeting a large enterprise the managers need those kinds of signals to trust you. $\begin{array}{ll}\text { To be honest, I don't have many interactions with entrepreneurs. I am very focused to do ourselves, so you know we have so much work to } \\ \text { Start-ups } & \text { do, our full time is spent with our head ---- just delivering. On what we need to do, so we probably don't actually act as collaborators in this }\end{array}$ building as many people would like us to be. We are not here to collaborate. In my incubator, there was nobody else that did what I did in my work there is more collaboration than competition.

Sometimes within, the thing is you don't build alliances with other start-ups, you do it with bigger companies. As a start-up, you want what you do not have a site and scaling credibility that you get with a bigger company. It can happen in the incubator when the partner is a large company if those companies see a benefit building an alliance with you.

university and ----university, beyond that we are partners ------------------- so we are partners there, we have been working with ---- which is an agricultural research university, we also received--- energy tablet --- a contract we have worked on a partnership with ---- and other innovation within the agricultural industry --- through them we have contracts with other animal feed companies.

There is a number of universities we work with including Crampton, -------- where I sit on the board of advisors, University of Bristol and U.C.L. so we are doing that, and we get value out of it. We are also taking interns and graduates --------- in addition, we have an academic initiative ---- for academics to use in their institutions.

We actually collaborate with Imperial college

-research and engineering, that is one part of our service that we are looking into, so we have a strong R\&D stream and a lock chain, so it is something we worked on together so ---- a prototype, but we are still in ---- study --working with students from the science departments.

A company like ours is highly judged when it goes on stage, we are in a very richly -------- in the broader sense of the word in a university but smart, clever people, who are not necessarily linked to an academic environment. But they academics, scientists or innovators, so the work we do is highly scrutinized, so you can’t approach it in a naive way, but to approach it in a highly intellectual way

I think they should do a better job of marketing for this community; we do not interact with any university in the U.K. not because I do not want to, but because the great amount of time and resources involved. I can work with AMAZON they come out and offer solutions, that is what the universities should do here. 


\begin{tabular}{|c|c|c|c|c|}
\hline Themes & Theme codes & Relevant Quotes & Interview & Code \\
\hline \multirow[t]{15}{*}{$\begin{array}{l}\text { Absorptive } \\
\text { capacity }\end{array}$} & $\begin{array}{l}\text { Knowledge } \\
\text { Spillovers }\end{array}$ & $\begin{array}{l}\text { Every time ------ there's always an idea, that in every situation, that somebody says something. It's not a fundamental change of strategy, but } \\
\text { it's an improvement, an enhancement, a twitch, a minor realignment and I perceive ---- into that. I'm constantly listening to that, that's very } \\
\text { hard for certain team members to cope with. }\end{array}$ & 3 & AB1 \\
\hline & & $\begin{array}{l}\text { Yeah, Microsoft would be one ----- but all the team absorbs knowledge, especially the younger graduates. I do tell them to go on courses ---- } \\
\text { stuff, sign up to these broadcasts, get as much information so we can short cut or create shortcuts, no point in developing something that has } \\
\text { already been developed, you use that absorption of knowledge to mousetrap what we do }\end{array}$ & 24 & AB2 \\
\hline & & $\begin{array}{l}\text { I did not have to. I was getting so much knowledge already that I could rely on and that was enough. We started working in a co-working } \\
\text { space at some point they tried to involve us, but the level was not the same. There are a lot of people are trying to build ecosystems that they } \\
\text { think will work out, --------------- they have a kind of an advantage. }\end{array}$ & 10 & AB3 \\
\hline & & $\begin{array}{l}\text { I believe in agile process ---- building something for five years and then it is something your clients don't want. I believe in communication, } \\
\text { so the better you communicate, the better your clients will feel that you want to communicate with them and build the products they DO want } \\
\text { to use. --- A nice to have a tool, but it is not what I paid you for. And they have to quit because they have to build the product in } 6 \text { months. }\end{array}$ & 18 & AB4 \\
\hline & & $\begin{array}{l}\text { What you have now in technology will be obsolete in a year or will be behind the curve of the year advance, so no matter how small you are } \\
\text { you always have to have a budget for R\&D. the program helps you think in new ways, so you are not only looking at your way, you are } \\
\text { happy to see things done in a different way. You have to have a starting word; our starting word is the word from our customers. ------, we } \\
\text { have to see if we can build that feature into our product. ----- We do not do it as a formal service, but we are listening to our customers. That } \\
\text { is where it starts from, and then we speed it to the product team, who speeds it to the technical team, product does the research. }\end{array}$ & 13 & AB5 \\
\hline & Human Capital & $\begin{array}{l}\text { Well, we create our own knowledge, the key thing is recruiting the right people, with the right experience and the right knowledge ---- were } \\
\text { developing a ------ manufacturing process, I can't buy that technology I can't go out and buy that technology, you develop it yourself and } \\
\text { you need people, skilled individuals, to be able to do that. You have to equip these people. }\end{array}$ & 2 & AB6 \\
\hline & & $\begin{array}{l}\text { We have a dedicated R\&D. Department, which counts with four people and we undertake a series of investigations background scientific } \\
\text { research on virgin technology trends, and then we look towards how we can commercialize our ideas. }\end{array}$ & 26 & AB7 \\
\hline & & $\begin{array}{l}\text { We are three major pillars in the company }-1 \text { marketing and sales. We have to do a lot of explaining to potential clients the problems and } \\
\text { solutions of their businesses, R\&D: engineering and technology. } \\
\text { When you build a software company } 2 / 3 \text { of your company are engineers, doing research, looking for new ideas. }\end{array}$ & 21 & AB8 \\
\hline & & $\begin{array}{l}\text { We have a very strict budget; we divide work, resources, intercourse way for a part, our relief is usually } 33 \% \text {. So the R\&D will be what we } \\
\text { need to develop our product we progress on our work, on what we want to deliver at any one time and the impacts it feels now, and then we } \\
\text { re-design a road map to work with those directional timelines. }\end{array}$ & 27 & АB9 \\
\hline & $\begin{array}{l}\text { Product } \\
\text { development }\end{array}$ & $\begin{array}{l}\text { So the approach you take is: you develop that technology, you develop it to a standard that meets the nature of the requirements basically, } \\
\text { so you take something that is purely research-based that may have fundamental issues and the original design and some technology used, and } \\
\text { you fix that so it's suitable to a commercial environment }\end{array}$ & 2 & AB10 \\
\hline & & $\begin{array}{l}\text { It's a small start-up, mainly it's getting customers in all the time. Probably two a week, we get customers and do testing. So, we build } \\
\text { something, test it with them, get feedback and change it. That's how. It's customary engagement rather than.... mostly it's directly with } \\
\text { customers. }\end{array}$ & 5 & AB11 \\
\hline & & $\begin{array}{l}\text { Mainly by me and my co-founder James. We are in the development stage now, but we have to do a lot of research; customer behavior, other } \\
\text { products that work well in parallel industries ----. Purely for testing purposes, we probably spent } 15.000 \text { on that. That is the most we have } \\
\text { spent on a project --- which we scrapped and are now starting from scratch. }\end{array}$ & 16 & AB12 \\
\hline & $\begin{array}{l}\text { Virtual } \\
\text { platforms and } \\
\text { search engines }\end{array}$ & $\begin{array}{l}\text { Well, I suppose all the classic one: Google researches a couple of universities have access to free academic tools. --- I would say that one of } \\
\text { the criticisms I have of my research team is that they are not very good at discovering stuff. }\end{array}$ & 24 & AB13 \\
\hline & & $\begin{array}{l}\text { We have data analysis tool; we have ----- we have various apps, what the people want. And we use GIROB to handle the R\&D, project } \\
\text { management Q.A., and delivery, we also use confluences, we can media a platform to capture data, and then to make sure we don't repeat ---- } \\
\text { it is written somewhere where we can have a look. }\end{array}$ & 19 & AB14 \\
\hline & & $\begin{array}{l}\text { We use -------- to organize anything we do ------------- that is part of the to do when I come across something interesting on a personal } \\
\text { level. I use pinboard to track the possible links. }\end{array}$ & 8 & AB15 \\
\hline
\end{tabular}


No, not yet because we are in a phase ----- so we can't get --------------- manufactured somewhere else, but there is a potential to do much in the future. We have investigated exploiting ------------ because through the open innovation, they have a group that collaborates with small biotech Start-ups. In that science park, but you can establish through contracts, you can establish the options to use ----- on technology --------and it benefits small start-ups, so you can use it and later the data they need--- and they make the decisions buying equipment.

For me to remain focused is more important than to build alliances. It is nice and cute but if you are innovating you have things that none have. And the vision of the world on how it should work, you really want to keep it to yourself. Unless there is, a commodity derived. I did not look into that too much.

Innovation for us is how we actually go on the market or the prize we are building for the market. The innovation is not in the technology; $\begin{array}{ll}\text { Technology } & \text { is how it is put together and presented to the World. What we did was look at the problem, the challenges presented, how can we make it } \\ \text { adaptation } & \text { better, ok it needs } 3 \text { or } 4 \text { components, ok, so how we combine those components in one innovator solution and that is pretty much what we }\end{array}$ have done we have found an innovative way to face that problem and what we have learned is that it is not only for international trade.

If you look at what somebody else is, doing it could benefit you ....spot an idea, or just try something different. So if you look at the music industry, you see how this is and why is that and you can see how to apply it and better your product. If I had a stronger resource, I would probably do that.... Yes, taking inspiration and see how and where you can apply it.

Process

They shared a lot, they gave us a lot of time from senior executives, well organized by the...... They want to show to their staff that they are working with start-ups. What they said to us was that they wanted to learn as much as how you work, as what you are doing.

A major put up in our business strategy because by learning from them and seeing how much value we can bring to them, made us realize that actually working with big start-ups. Was going to be better than standing on the street and maybe trying to build our branch. Our focus has really changed from $\mathrm{B}$ to $\mathrm{C}$, to $\mathrm{B}$ to $\mathrm{B}$ to $\mathrm{C}$. the whole business probably has to change because of our strategy.

Experiments $\quad$ we once commissioned a project with a formula one engineer, expert in simulation so taking formula one expertise and bringing it to the used car market is something never done before, that was my first experience seeing innovation as a possibility at that time.

I listened to a postcard last October, and I came to the office and said let's try this experiment, and it took four weeks to try it, and it proved to be a great success. Experiments are the main mechanism that we use; we have a control team to match result with the experiment, Essentially the financial role of any startup is the huge problem for the first couple of years, ---out of money, but we are still around thanks to
Funding $\quad$ drop the funding and concentrate on the product, I had to use the plan B because we had run out of me. In September, I prepared the ground for the hard landing.

The funding that we got until now has gone to build our prototype, on further R\&D, as we were working with Imperial students, there was no budget allocated for that. Until now ----- how we invest the money.

We would like to grow and go further and move from the U.K. to the U.S. in general terms. But we want to build products that innovate -------- driven more ---- giving the right product to the right people -------- that is the most important to us than anything else to see an idea grow to an actual product that the people love, and because of it you see the industry change you become a start-up ----------- to see growth in a right way.

We could not grow fast enough to have enough supply because we were a linear model and became a market place model and that was an innovation in our industry, how we source products ---- and being in 200 different cities can only be done with innovation. That was the $2 \mathrm{n}$ level of strategic innovation that we made from a 10-million-dollar company to a 50 or 100-million-dollar company 